\title{
Power Resources and Income Inequality in Switzerland and Singapore
}

\author{
Pre-print version \\ M Kerem Coban \\ Published in Singapore and Switzerland: Secrets to Small State Success, edited by Yvonne \\ Guo and JJ Woo, pp. 255-284. Singapore: World Scientific.
}

DOI: 10.1142/9789814651400_0011

\begin{abstract}
This chapter endeavours to explain rising inequality in Singapore and Switzerland from a power-resource theory perspective which will be accompanied with the idea of trilemma between earnings equality, full employment, and budgetary restraint. Recent decade has observed rising inequality in two countries, and this chapter mainly argues that the limited role of labour in policymaking process seems to be one but critical explanatory variable in highly decentralised and centralised political context in Switzerland and Singapore, respectively. Besides the role of political institutions, distinct experiences with labour unions, historical evolution of social policies, the need for more integration with world economy, and ageing are also taken into account for a comprehensive understanding of forces behind rising inequality which is instrumented as the gap between top and lower income deciles. This chapter concludes that all forces interdependently play their respective roles; meaning it is difficult to separate one from another. Finally, it calls for being responsive to incessant changes in domestic arena with a focus on shifts in demography, labour demand, aspiration of the youth while maintaining soundness of fiscal capacity.
\end{abstract}

"[W]e conclude that the concentration of wealth is natural and inevitable, and is periodically alleviated by violent or peaceable partial redistribution. In this view all economic history is the slow heartbeat of the social organism, a vast systole and diastole of concentrating wealth and compulsive recirculation"

Durant (1968: 57)

\section{Introduction}

In the aftermath of the global financial crisis in 2008, both public and policymakers have become aware of rising income inequality in both developed and developing countries. Piketty's (2014) controversial book reignited the debate as to why inequality has been rising, and how to react with proper policies to minimise social, economic, and political by-products of rising inequality. At the same time, many existing theories about inequality have also been challenged. For example, Kuznet's (1955) inversed-U-shaped hypothesis of firstly rising, secondly reaching a plateau, and then finally declining income inequality with respect to level of economic development can no longer be observed particularly in developed countries (Galbraith, 2012). It has transformed into a horizontal S-curve, showing that instead of decreasing, inequality increases after a certain level of economic development. 
This chapter attempts to explain rising inequality in Switzerland and Singapore through a political economy approach, by using the framework of power resource theory and focusing on the relative political strength of trade unions. The change in relative political strength of the trade unions and labour movement is hypothesised to be one of the determining factors leading to rising or declining inequality. This chapter explains why both of these countries have taken different trajectories since the 1990s when the Swiss government began to allocate more funds to social spending.

\section{Power Resources and a Trilemma in a Service Economy}

How the fruits of economic activity are distributed are "who gets what, when and how" (Lasswell, 1958[1936]) is a political problem stemming from a series of political decisions. This problem requires an analysis of where actors in this political decision-making are located. Moreover, their relative strength in convincing other actors to comply with their causes depends on their relative positioning in this "bargaining game."

Framed in this light, rising income inequality, as explained cogently by Piketty (2014), is a phenomenon of the dominance of capital vis-à-vis labour. As wage share in gross domestic product (GDP) has declined in recent years (Stockhammer, 2011); the relative political influence of the labouring classes ${ }^{1}$ is assumed to have declined with the "rise of capital" and its power to "exit" (Hirschmann, 1970) as global capital mobility has increased significantly since the 1980s.

Korpi's (1983) analysis on class struggle particularly in Western capitalist democracies shows that the relative bargaining power of the labouring classes rests upon power resources in particular the emergence of trade unions. According to Esping-Andersen (1985), political representation (as opposed to revolution) has become one of the major paths for the labouring class to influence the political bargaining process from within the parliament. Consequently, as Korpi points out, any change in relative strength can change the outcome of the bargaining and the functioning of the bargaining system ${ }^{2}$, but it all depends on how power resources are divided between actors (Ibid: 19).

Here, it is important to briefly mention why we may need to analyse the role and impact of trade unions on income inequality. In a recent study by the staff in the International Monetary Fund (IMF) argue that since the 1980s, rising income inequality in high income countries is highly associated with declining union density rate (Jaumotte and Buitron, 2015). Keeping in mind that unions' activism in early $20^{\text {th }}$ century led to development of social welfare State particularly in the Western Europe (Acemoglu, 2012), declining union density rate can explain about half of the rise in the share of top 5 percent and 10 percent income share in high income countries in the sample since the 1980 s.

The unexplained part in the power resources theory is about the role the State. According to Iversen and Wren (1998), the State faces a trade-off between three factors: earnings equality, (full) employment, and (public) budgetary restraint. When it chooses fiscal

\footnotetext{
${ }^{1}$ In this chapter, I refer to "labouring classes" as a generic concept to define labour as forming a "class" on its own, for the sake of simplicity, without further discussion of how classes are formed or if labour includes all working classes. The interested can read a Marxist interpretation of social classes in Poulantzas (1973); and a discussion of the formation of class structure according to the Weberian tradition, the social democratic interpretation, and others in Esping-Andersen (1985: 26-36).

${ }^{2}$ It undoubtedly depends on various politico-economic ecosystems in which each actor is positioned according to the unique experiences of a given country. This is in line with "varieties of capitalism" (Hall and Soskice, 2001) which give way to dissimilar wage setting institutions either centralised or decentralised (Wallerstein, 1999).
} 
discipline, it has to either choose earnings equality or employment growth. If it combines fiscal discipline with employment growth, it tolerates depressing wages in what the authors call "neo-liberal model." The second combination is fiscal discipline accompanied with earnings equality, labelled as the "Christian democrat model." Finally, if earnings equality is accompanying employment growth, it is labelled as the "social democratic model."

We can assume that the power resources of parties engaged in the political decision determine the choice of the model; the relative strength of the labouring class to influence the political decision-making process determines the outcome of the bargaining process. What it can gain can purely depend on its influential power. This chapter will assume power resources as given, so it is not concerned with how resources are divided ex-ante. Nevertheless, in line with Korpi's (1983) arguments, we can expect that division of power resources do in fact determine the process. Furthermore, the trilemma presented by Iversen and Wren (1998) shows that one of the three models is adopted through the bargaining process within their respective borders. By mobilising these two analytical frameworks for the Swiss and the Singaporean cases, we should expect to observe that some sort of "neoliberal" model has been adopted in Singapore due to several reasons to be discussed below; whereas the Swiss case shows first a pattern of a "Christian democratic" model until the 1990s which then evolved into more of a "social democratic" model in the aftermath of the long recession in the early 1990s. The relative strength of the labouring class that is mobilised through trade unions and/or leftist parties determines the choice of these models in the two cases. The highly centralised government system in Singapore (Régnier, 1987), and its unique history with unions and a story of independence and survival contrasts sharply with highly decentralised federal system in Switzerland (Linder, 1994; Obinger 1998) and its different political system and political institutions to form one critical explanatory variable in income distribution and the evolution of social policies in both countries.

\section{The Swiss Case}

The unique political institution of direct democracy plays a critical role in policymaking in Switzerland. Wagschal (1997) points out that direct democracy requires the mobilisation of different actors to change the course of a policy at the federal level. In order to change policies, the Swiss have three options: (a) constitutional referendum - which requires double majority of the votes and 26 cantons; (b) optional (facultative) referendum - which requires signatures of 50,000 voters, but can be challenged by a counter initiative; (c) a popular initiative - to amend the constitution or changing current provisions in the constitution; and requires signatures of 100,000 voters (Wagschal, 1997: 228-9). Even if the labouring class is successful in mobilising voters to alter provisions in the favour of expansionary welfare spending, the result of voting may not guarantee expansion in spending. Wagschal (1997: Table 2) provides evidence on referenda in Switzerland from 1848 until 1996 that 19 referenda out of 40 rejected an increase in taxation, 28 out of 42 referenda resulted in rejection of increasing expenditure. Consequently, climbing up from a decentralised and a local context of a cantonal level to a federal level demands great effort from the labouring class to influence policies; and as the historical evolution shows, country-wide initiatives are generally rejected. 
The difficulties of direct democracy generated on mobilisation of groups to alter terms and conditions of social spending at the federal level. Bertozzi and Bonoli (2003) show that high costs of mobilisation paved the way to local arrangements at the cantonal level. They present varying degrees of social welfare policies in 26 cantons. None of them provide the 'full menu' of social policies such as aid to families with children, allocation of individual housing, long-life social security (Bertozzi and Bonoli, 2003: Tableau 3); however, they provide several of these policies at differing degrees. Obinger et al. (2005) argue that it was the 'local pre-emption' at the cantonal level to introducing social welfare policies mainly driven by non-existence of these policies at the federal level. The authors argue that it was in 1893 when the labour movement called to improve the conditions of the labouring class, but it was rejected at the federal level under the influence of the so-called bourgeois government (Obinger et al., 2005: 276). Additionally, in the early twentieth century, the Radical and Social Democratic parties presented a law on the general pension scheme; and it was rejected by the federal government due to fiscal costs. The presented data and historical evidence can be interpreted according to power resource theory that the relative strength of the labouring class in influencing local level politics and political decision-making on social welfare policies was stronger compared to that of at the federal level.

The strong presence of the "third sector" in the country has played its role in complementing private and public spending on social welfare. Butschi and Cattacin (1993) argue that industrialisation in Switzerland led to questioning of the ways to take care of the labouring classes. The Church, family and solidarity organisations constituted the first pillar of the social welfare system in the country. As the authors explain, industrialisation changed conditions the labouring class was facing, so the political elite became cognizant of the potential of social and economic aspects of it. The State was forced to engage in the social welfare system later on, as Armingeon (2001) and Katzenstein (1985) define Switzerland as a "laggard" in developing a social welfare system. Cattacin (2006) underlines the role evolving role of solidarity organisations such that they were first utilised as a subsidiary to the State, but then their role has been now evolved to a complimentary role as State is much more involved in the social welfare system.

Finally, with respect to political parties representing the labouring class and their relative strength and positioning, the bourgeois governments are mostly positioned to protect the interests of business, prefer self-regulation, self-dependence among the public (Obinger, 1999). The federal political institutional environment created a fragmented and relative weak labour movement that can hardly mobilise its representatives at the federal level, despite having some achievements at the cantonal level (Katzenstein, 1985: Obinger, 1998). The dominance of the bourgeois governments since 1975 until today has been recorded in Beck et al. (2001). The Social Democrats were only dominant in the 16 years between 1975 and 2012. The majority of the 'winning coalition' was the right-wing parties such as the Radicals and currently the Swiss People's Party. Both of them share fiscal discipline, low tax rates, self-dependence, and also less dependence on subsidies.

All of these factors have seemingly played their respective roles in the development of the Swiss welfare state throughout the history. The recent years, since the early 1990s, as Figure 1 and Figure 2 show, have been witnessing the development of the Swiss welfare State with greater involvement of the Swiss government through expansion in public social spending. 
Trampusch (2010) calls this era the "post-liberal" welfare regime because the "liberal" regime was similar to the "neo-liberal" model of Iversen and Wren (1998) discussed above. The author argues that trade unions have started increasingly to use popular initiatives to mobilise the labouring class and to influence federal level politics. For instance, trade unions were successful in countering amendments in labour law and unemployment benefits in 1997 (Trampusch, 2010: 68). This trend of greater use of popular initiatives, collective bargaining issue was not a real concern in the country thanks to strong labour market. The low level of labour force, strong economic performance, and favourable fiscal position allowed the country to enjoy benefits of low level of unemployment, and without greater engagement of the federal State to provide social welfare until the early 1990 s.

The decentralised, individualised, and company-level wage determination is argued as no longer benefitting the labouring class because the economic distress hurt the labouring class in the early 1990 (Oesch, 2011). As a result, Oesch (2007: 342 cited in Trampusch, 2010: 69) underlines that a "process of learning" among the trade unions motivated them to overcome the fragmented union system in the country by merging several unions with one another. By doing so, their collective strength was boosted countrywide. However, it should be noted as well that Armingeon (2001: 162) explains persuasively a particular policy innovation of the federal State. It started balancing demands from capital and the labouring class. To give an example, women's retirement age has increased; in the meantime, the level of pensions has increased as well. By merging these two policy instruments to balance demands from the remaining two parties, the State seems to search for opportunities to be the broker between capital and labour.

In light of major potential determinants of income inequality, Switzerland does not seem to be an outlier among developed countries, where earnings inequality is declining. Figure 1 shows that the share of the top $10 \%$ income level reached its historically highest point in the last decade. The ratio of top $10 \%$ and bottom $90 \%$ levels of income had reached a level close to 4.5 before the Second World War, but it then declined and remained at a relatively stable level. The ratio started to go up in the late 1990s, and it has recently reached the level of 4.46 in 2009 . The share of the top $10 \%$ income level in the whole "cake" reached its historically highest point of 33.15 percent in 2009. In brief, earnings inequality has been increasing in Switzerland particularly since the early 1990s as Figure 1 shows. 
Figure 1: The Earnings Disparity between Top 10\% and Bottom 90\% Income Levels, Switzerland

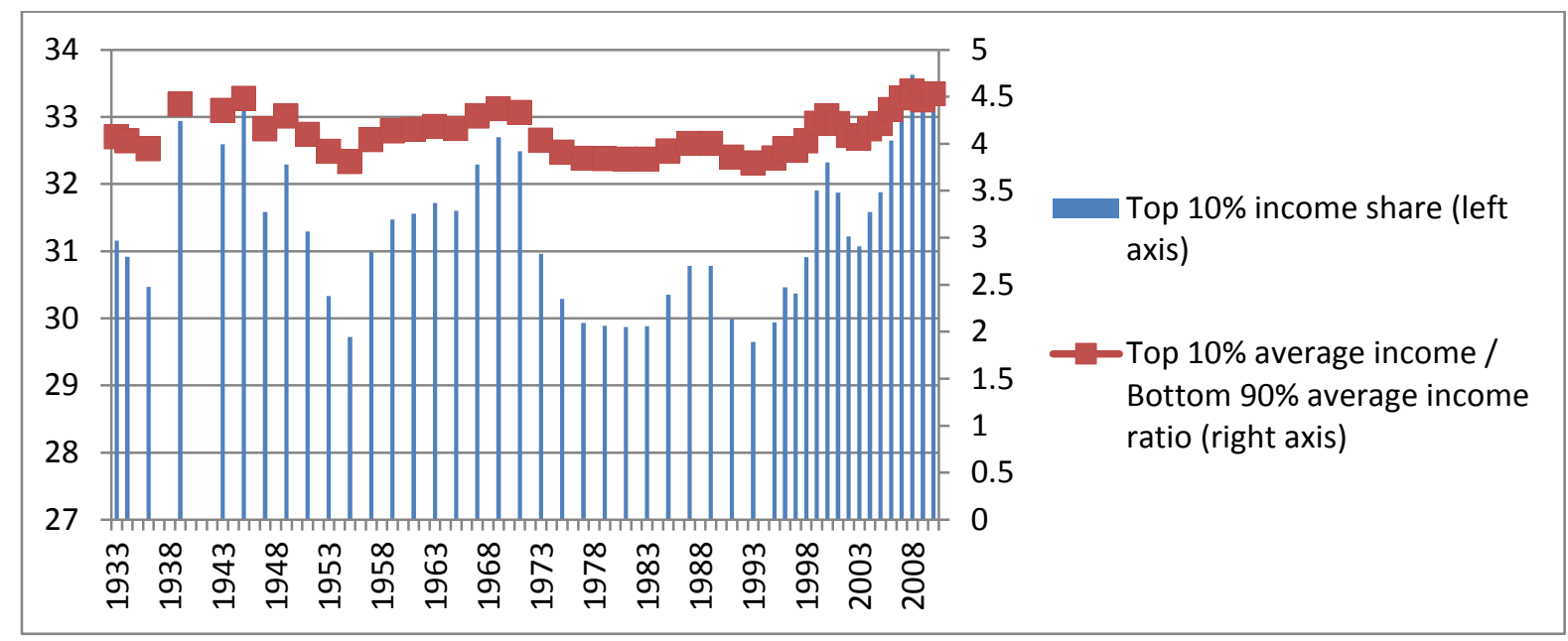

Source: World Top Incomes Database, http://topincomes.g-mond.parisschoolofeconomics.eu/, accessed on April 24, 2014

Note: Top $10 \%$ and Bottom $90 \%$ average income is real 2010 Swiss franc

Figure 2: Subsidies and other transfers, \% of Government expenses, Switzerland

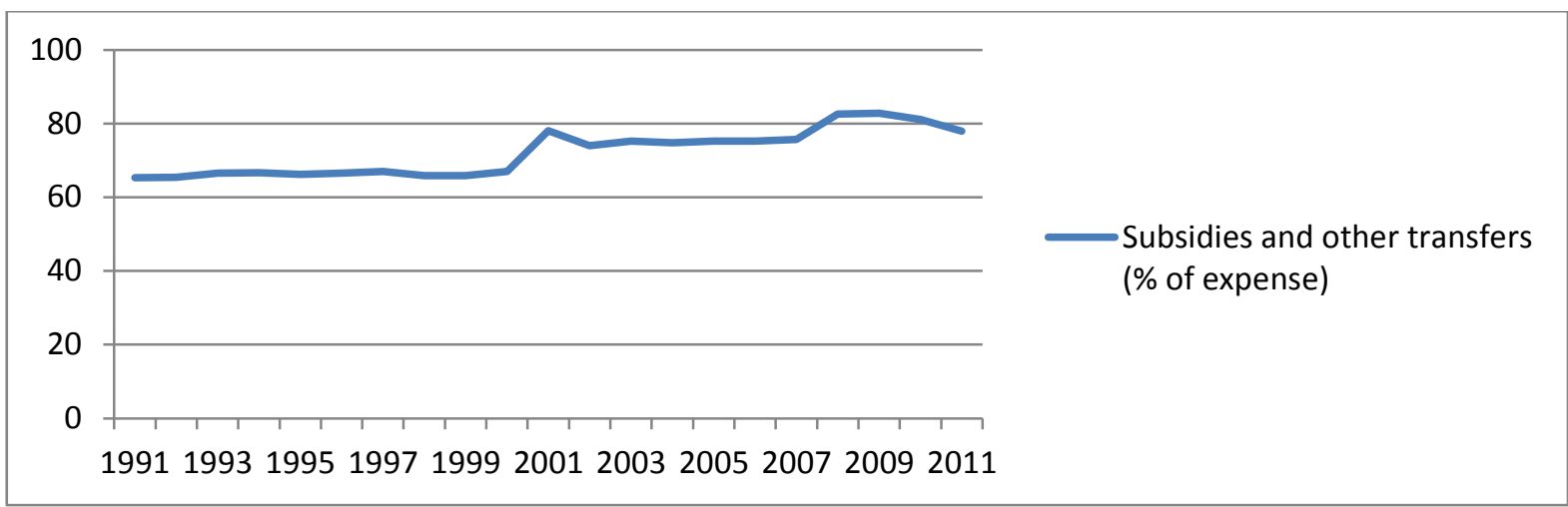

Source: World Development Indicators, the World Bank, accessed on April 18, 2014

With respect to government expenditure on subsidies and other transfers, the Swiss government has been spending around 65 percent of its total government expenses on those items since the early 1990s onwards for which the data are available (see Figure 2). Figure 3 indicates that the share of general government spending was very low less than 10 percent to a ratio of GDP; however, it has gone up from that level since the mid-1970s, and has been steadily above 10 percent of GDP. While it has stayed at a level above 10 percent of GDP, the yearly growth rate of government spending shows that since the 1990s, fiscal discipline which can be here defined as lower growth rates compared to the previous performance, has slowed down although the upward shift after the global financial crisis in 2008 is a global phenomenon as many countries around the globe has resorted to expansionary fiscal and monetary policies. In the meantime, health expenditure of the government has gone up expectedly due to two major drivers: (a) ageing in the Swiss population; (b) increasing levels of social security spending since the early 1990s. 
Figure 3: General Government Expenditure and Health Expenditure, Switzerland

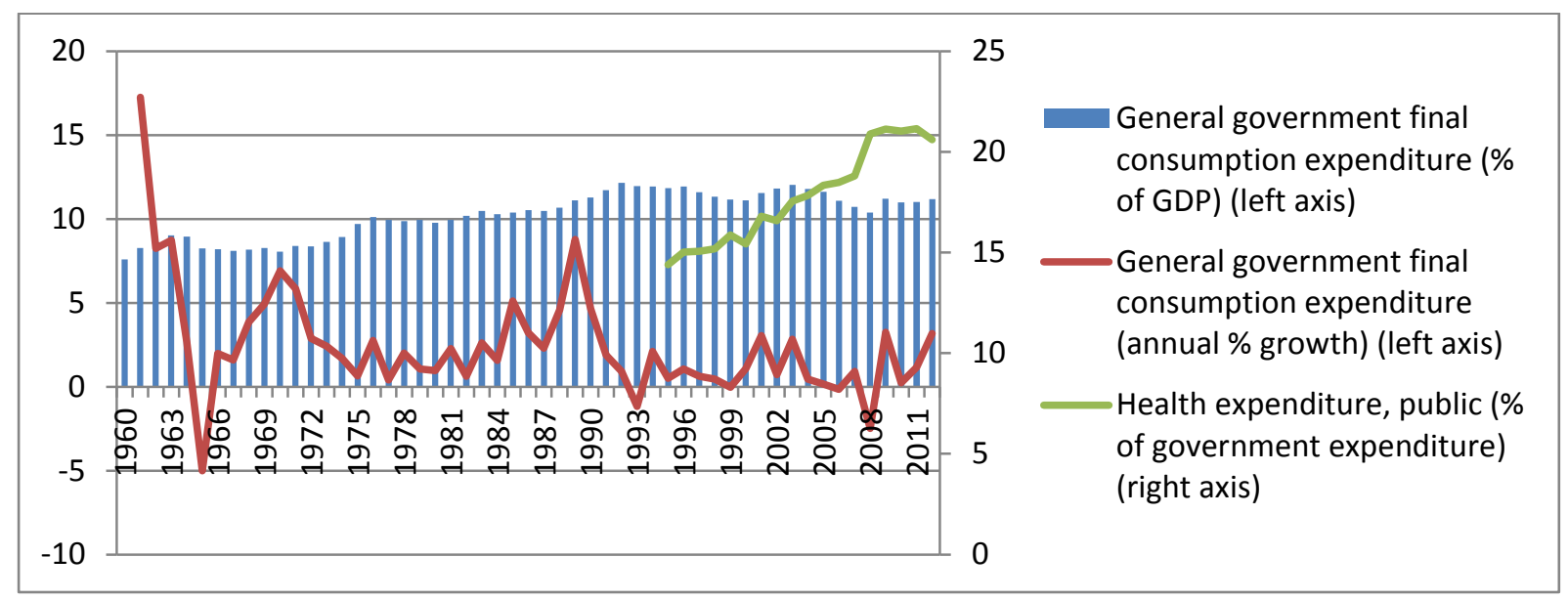

Source: World Development Indicators, the World Bank, accessed on April 18, 2014

These indicators show that the Swiss government has been expanding its expenditure on social needs of the Swiss population, at least since the early 1990s. It should be noted here that as Figure 4 depicts the story of evolution of unionisation in Switzerland, net union membership among the wage and salary earners has been declining since the late 1970s. According to collective action theory and power resource theory, we would expect to observe a different link between increasing government social spending and the strength of unions; however, the declining membership overlaps with increasing level of social spending. We will try to answer the trend that is contradictory to our intuition through looking at relative strength of labour movement, and the political institutions in the country.

Lipset (1983) mentions that Switzerland has never witnessed radical mass mobilisation firstly due to introduction of political rights in relatively earlier periods, and secondly because industrialisation had not led to massive urbanisation (Obinger, 1998) that could have eroded social ties and rural institutions of communal cooperation and redistribution in Polanyi's interpretation of consequences of rise of industrialisation and self-regulating market economy (Polanyi, [1944]1975). The non-existence of such radical movements resulted in the absence of radical labour unions, which could have translated into higher expectations for social transfers and scepticism of a strong federal State vis-à-vis cantons (Linder and Vatter, 2001).

Baur et al. (2013: 16) underline that "the federal government levies around one third of total taxes and likewise accounts for approximately that proportion of total public expenditure." The cantons shy away from leaving their internal independence to the federal State. As a result, the fragmented and relatively less developed federal governmental functions make it harder for the labouring class to influence federal level social security policies that would reduce inequality country-wide. The federal political institutional setting has been shown to impede the development of a welfare state in Switzerland. Obinger (1998) argues that the number of "veto players" and multi-tiered negotiations to change federal policies result in a particular type of "path dependence" halting the process of increasing welfare spending at the federal level. Pierson (1995) also shows for the Canadian and the United States cases that development and management of social welfare in federal political systems is more 
likely to be harder than other contexts due mainly to competition between local political entities, and the federal level influence of business interest groups.

Figure 4: Net union membership as a proportion of wage and salary earners in employment (\%), Switzerland ${ }^{3}$

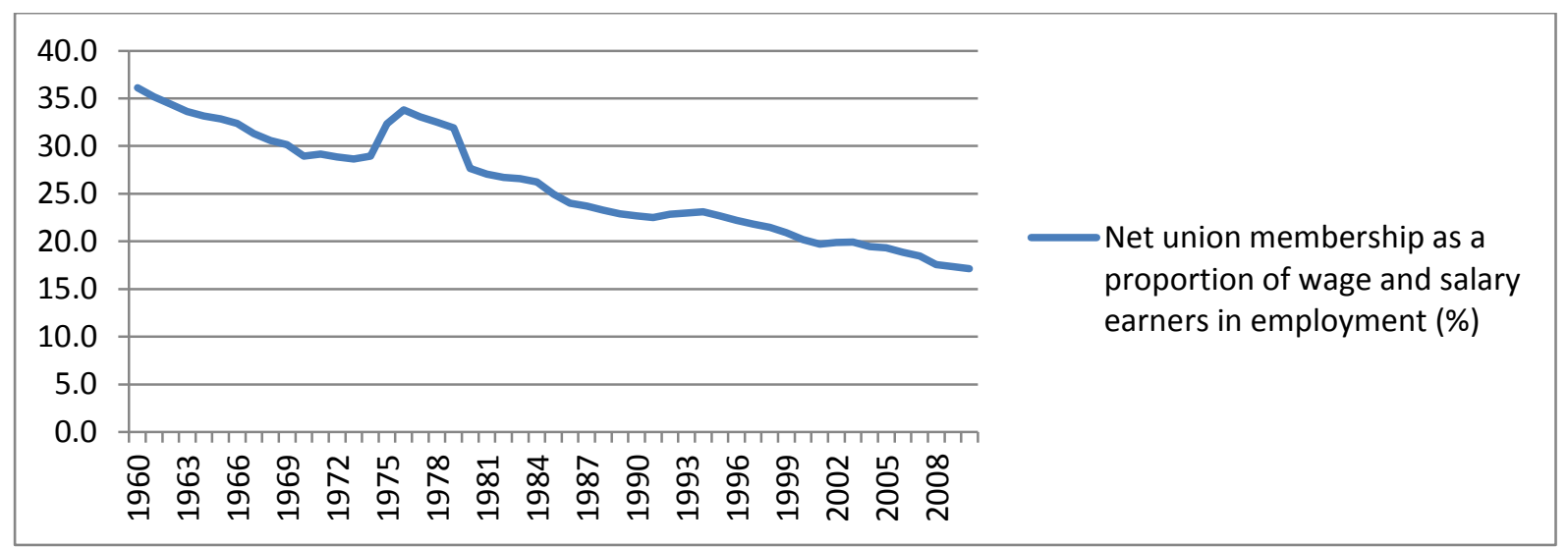

Source: ICTWSS Database, http://www.uva-aias.net/208, accessed on April 18, 2014

In recent years, with the recognition of the benefit of collective effort to bring issues to general concern at the federal level, trade unions seem to be more active in bypassing multitiered negotiations from the cantonal level to the federal level. A recent and a good example of those recent attempts would be the role of trade unions in bringing issues to the federal level would be best shown with the recent attempt of the collective effort of unions and several affiliated non-profit organisations to bring the issue of minimum wage to a level of popular vote on May 18, 2014..$^{4}$ The Swiss Union of Syndicates, ${ }^{5}$ which is an umbrella organisation of many trade unions, had headed the group in this initiative. The initiative campaigned for a minimum wage of CHF4,000 (i.e. CHF22 per hour) applicable at the federal level. The popular initiative was rejected against negligible support because 76 percent of the Swiss voted "no" for the initiative. ${ }^{6}$ The results show a dramatic "death" of the initiative as the percentage of electorate saying "no" to the initiative is remarkably high than that of those said "yes" (i.e. 76 percent versus 24 percent). When the result is analysed with some attention to federal political institutional context, and declining union density rate; trade unions seem to make attempts to address rising income inequality. However, the multiple "veto players" on the road to get the issue formally recognised as an agenda item at the federal level is stuck with the result of the popular initiative in May 2014. This example shows that although trade unions might be more willing to work within this politicaleconomic structure to influence wage policies at the federal level, that structure imposes

\footnotetext{
${ }^{3}$ According to Amsterdam Institute of for Advanced Labour Studies ICTWSS database, union density rate is equal to NUM*100/WSEE; where NUM is "net union membership"; and WSEE is "wage and salary earners in employment." Net union membership is calculated as follows: (total union membership) - union members outside active, dependent and employed labour force. WSEE is equal to employed wage and salary workers whose data is gathered from OECD, Labour Force Statistics. The ICTWSS Codebook is available at: http://www.uva-aias.net/208, accessed on April 18, 2014.

${ }^{4}$ For further reference to that particular initiative, the readers may refer to website of the initiative that is available online at http://www.salaires-minimums.ch/linitiative/, accessed on April 2.

5 For more information about the union, readers can refer to the website of the Swiss Union of Syndicates, available at http://www.uss.ch/luss/qui-sommes-nous/, accessed on April 2, 2015.

${ }^{6}$ The results and the distribution of votes based on the cantonal level is available on the website of Tribune de Genève, http://www.tdg.ch/suisse/salaire-minimum-rejete-77-suisses/story/10325405, accessed on April 2, 2015.
} 
challenges for them; which in turn makes the efforts of trade unions to better influence the process.

In brief, as trade unions have become more centralised, and presumably started to influence employers and the State through collective bargaining in recent decades, we can interpret the current rise in social welfare spending in Switzerland through the lens of the theory expecting them to have gain relatively higher level of resource to project power in the political decision-making process. Throughout the history, the federal political institutional environment, fragmented trade unionism, the dominance of bourgeois governments in Swiss politico-economic system, have had set up high walls against maturation of the welfare regime in the country. With the economic distress in the early 1990s, and a "learning process" among the trade unions, Switzerland recognised the need for a social welfare regime during the "hard times" in previous decades. Although unions seem to have difficult times to have their concerns recognised by the federal State and a larger segment of the population, as was the case in the latest minimum wage initiative in 2014, we may expect income inequality to remain where it is today. This is a fair assumption given several conditions argued in this chapter; namely a decentralised political-economic institutional structure, declining rate of union density rate; even if trade unions seem to have recognised benefits of collective effort to carry issues of general concern at the federal level.

\section{The Singaporean Case}

In terms of earnings inequality, Singapore seems to rank ahead of Switzerland. This is not limited to a short period of time but indeed throughout the history of the city-State. The average income share of the top 10\% income level has almost never been less than 30 percent which has reached its historical record levels since the late 1990s. Income disparity between the top $10 \%$ and the bottom $90 \%$ income level has also widened reflecting the rising share of in the top $10 \%$ income level (see Figure 5). In comparison to Switzerland, this historically stable income disparity presents a unique case in a small country context. It is also unique in terms of general government spending (see Figure 6).

Government consumption seems to be anchored at 10 percent of GDP, although there has been several times the government had to spend more; however, the statistics signal that the Singapore government has chosen the "neo-liberal" model of Iversen and Wren (1998), which includes fiscal discipline and full employment. The aspect of full employment in this policy mix will be discussed below when we touch upon flexible wage determination and non-existence of minimum wage in the country.

The annual percentage growth of government expenditure draws a mixed picture because several economic shocks had driven the government to respond to these crises through expansionary policies. Health expenditure seems to have recovered during the last decade. Concessions on the "pioneering generation" should be expected to increase health expenditure of the government as the government appears not to increase spending when the economy is operating on sound economic performance and to share it with the ageing population that contributed to development of the city-State. Although prospects may sound as if welfare regime might be on a track that would expectedly benefit the Singaporeans, more has to be achieved to reduce earnings inequality in the country by 
reconsidering the growth model, minimum income, immigration, and even public housing (Low and Vadaketh, 2014).

Figure 5: The Earnings Disparity between Top 10\% and Bottom 90\% Income Levels, Singapore

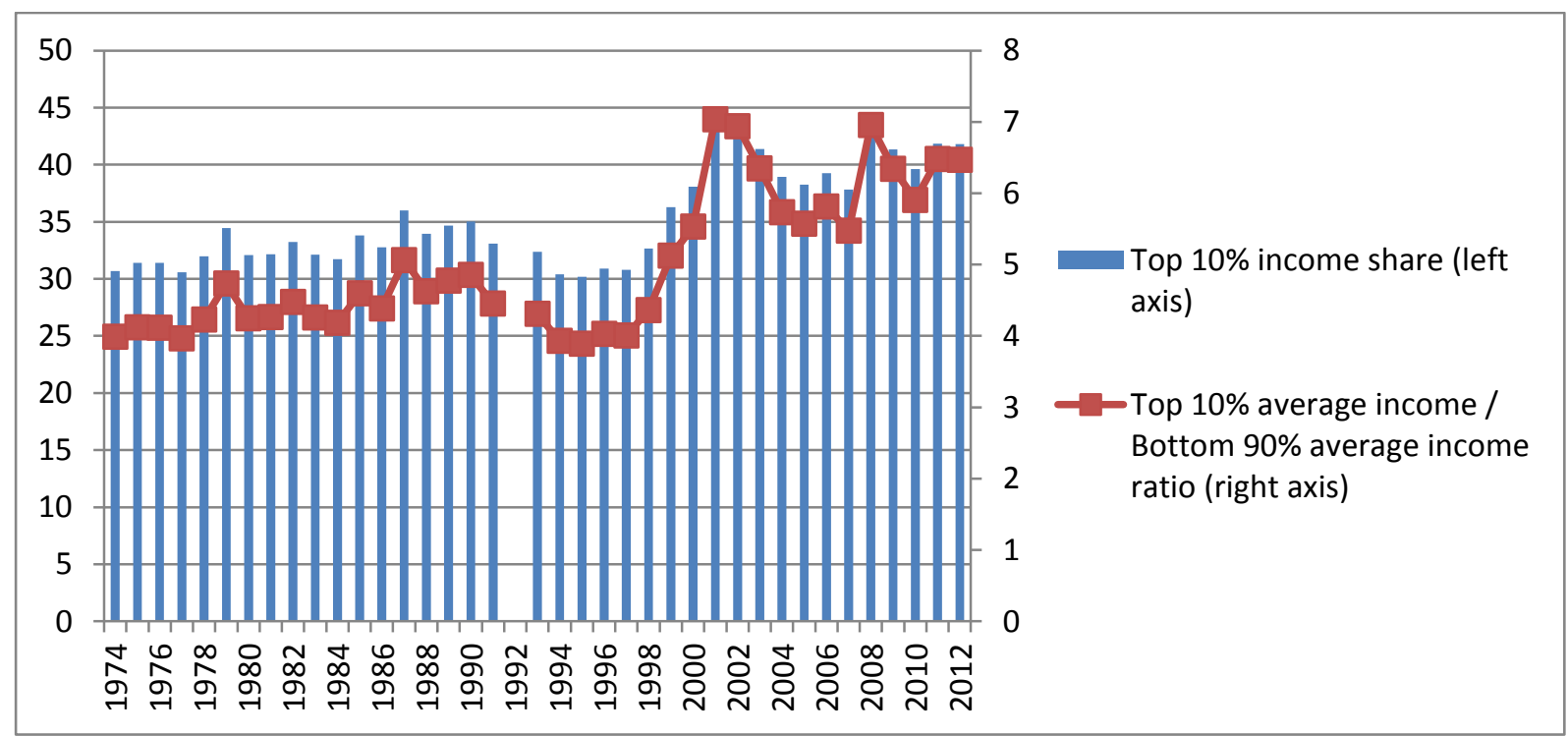

Source: World Top Incomes Database, http://topincomes.g-mond.parisschoolofeconomics.eu/, accessed on April 24, 2014 Note: Top $10 \%$ and Bottom $90 \%$ average income are real 2014 Singapore dollars

With respect to the role of trade unions, although there have been several upward shifts in union density (i.e. membership of wage and salary earners), Figure 7 shows that even if the trend has recorded recovery in the mid-2000s, it declined again and we need to see how it will evolve in the coming years and decades. As mentioned above, decline in unionism is a contemporary phenomenon (Pontusson, 2013); and Singapore is not an outlier by keeping its labouring force unionised, regardless of its desirability from the perspectives of the government and capital. In Switzerland, the limitation on trade unions to influence the federal level political decision-making on welfare policies and the overall regime is due to the decentralised institutional environment where the federal State is also facing its own limitations in terms of taxation, public spending, and even administrative system reaching the whole country. Cantons envy their relative autonomy, so trade unions have to mobilise resources to influence canton-level politics. Obinger et al. (2005) have shown that they were successful in doing so.

Consequently, we can assume that in smaller political units where trade unions might need to cope with a lesser degree of limitations; welfare policies could be much easily channelled. In Singapore, the unique experience of a highly centralised political system, scepticism on potential of a communist movement (Lee, 2014; Mahbubani, 2014), and the tripartite coordinated wage setting framework which includes the representatives of the labouring class, National Trade Unions Congress (NTUC), the government, and the business sector; posed impediments in its own nature in the city-State. The remaining part of this section will discuss the role of the centralised political regime and the role of trade unions in accessing the political arena to push for a better welfare regime in Singapore. 
Figure 6: General Government Expenditure and Health Expenditure, Singapore

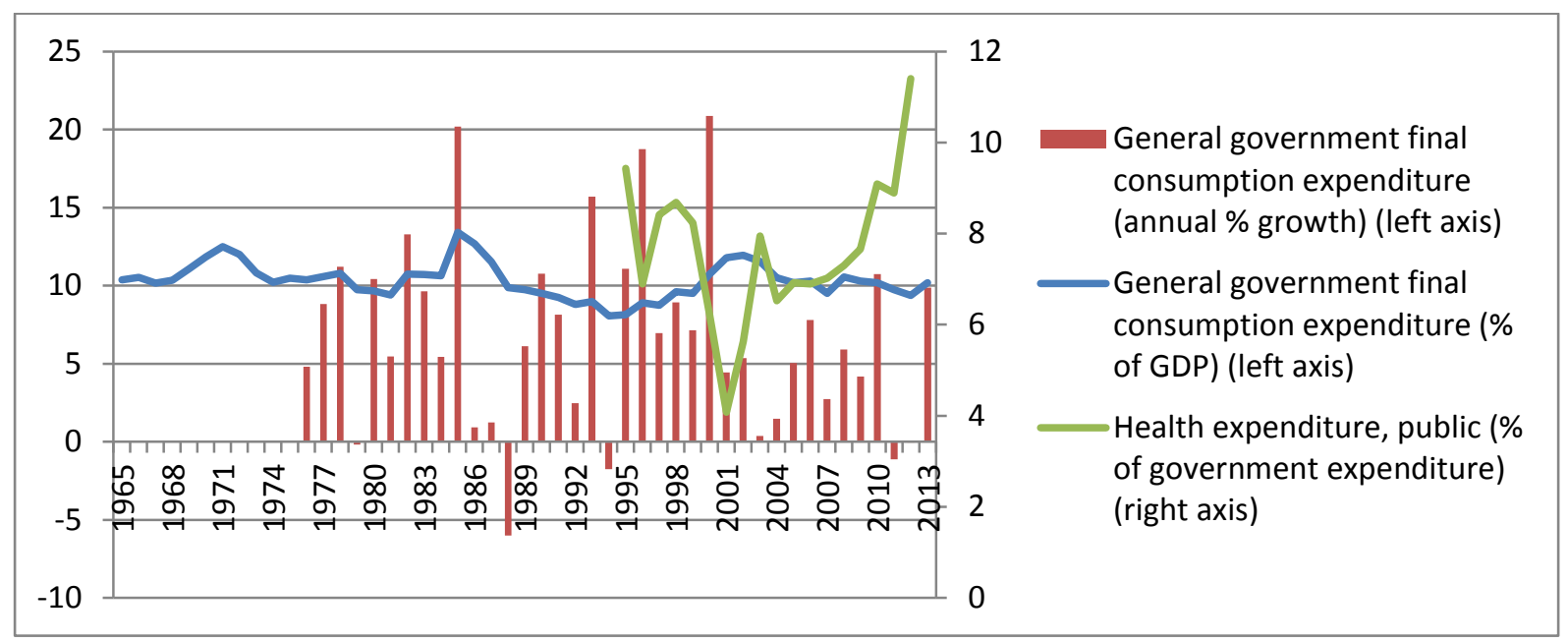

Source: World Development Indicators, the World Bank, accessed on April 18, 2014

Figure 7: Net union membership as a proportion of wage and salary earners in employment (\%), Singapore

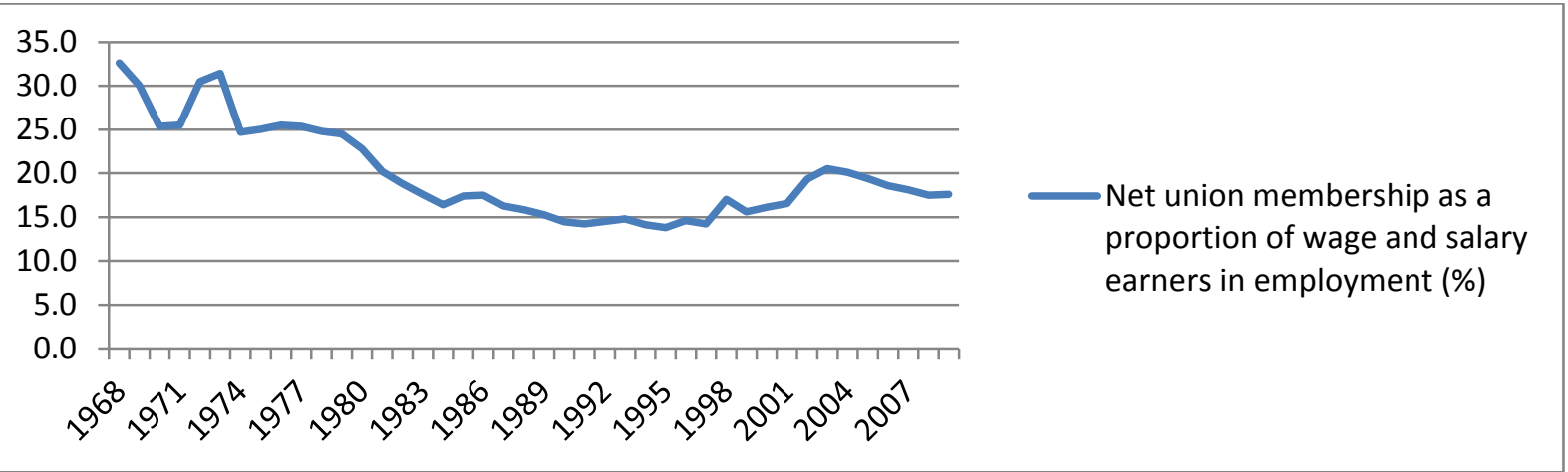

Source: ICTWSS Database, http://www.uva-aias.net/208, accessed on April 18, 2014

To start with the direct channel for the trade unions in Singapore to influence social policies; whose one of the major component could well be considered to be earnings of the labouring class (i.e. wage and salary); the wage setting institution in Singapore is a structure of a coordinated decision-making body that is formed by NTUC, the Singapore Government, and the representatives of the business sector. This tripartite body is called National Wage Council. The Council is headed by a chairman who is expected to be neutral to three parties. The Founding Chairman of the tripartite Council, Lim Chong-Yah (2014: 8-9) explains, the Council operates on two major principles; (a) unanimity; (b) Chatham House rule. The former requires unanimous decision-making in the Council, so each party has to agree on the terms. The latter indicates that whatever is discussed inside the meeting room is not disclosed so that each party does not have to be worried about their positions being publicly known. They can protect themselves against backlash if their position during the meeting differs very much with that of in front of public. When discussing wages, Lim (2014: 17-8) reports that the Council considers a guideline composed of quantitative and qualitative items. The quantitative guidelines starts off with a benchmark annual percentage increase with respect to macroeconomic conditions, and as Lim (2014: 18) reports the annual percentage increase was between 2 percent and 6 percent. The qualitative guideline is more about the wording and punctuation; which shows the ways how the ultimate decision is disclosed. Since 
introduction of minimum wage is still controversial in the city-State, Lim (2014: 19) mentions that he dropped the idea because he thought it would not be beneficial for Singapore. Above all, he mentions that he was inspired by Milton Friedman's seminal book Free to Choose that made him reconsider unintended consequences of passing stringent (economic) laws that may cause unemployment. Putting aside ideological orientation of key policymakers, Lim (2014: 22) also argues that firms do not have to obey national guidelines provided by the Council. They are flexible enough to negotiate with sectoral and/or firm-level trade unions. Even though a centralised wage-setting institution can provide favourable terms from the perspective of the labouring class, the flexibility enjoyed by the private sector seems to leave the labouring class at the mercy of the employers. ${ }^{7}$

In such a centralised wage-setting institutional context that is complemented with a flexible and a decentralised bargaining context, the role of the unions and thereby the labouring class could be expected to be marginal. ${ }^{8}$ Besides limitations on the role of unions to have a greater hand on the policies, the history of the experience of trade unions in Singapore since colonisation did not provide favourable conditions which could have provided a solid background on which the industrial relations would have been established. Rosa (1990) draws a clear picture of a turbulent history of the role of unions, and how and why they were incorporated in the National Wage Council later on following the independence. Rosa's (1990) study shows that the predecessors of modern unions had been formed previously as trade guilds in the 1930s. After the Second World War, the relative strength of the labouring class increased due mainly to high demand to reconstruct the demolished infrastructure (Rosa, 1990: 489). The General Labour Union of Singapore, established in 1945; and the PanMalayan General Labour Union, established in 1946; can be conceived as the origins of current unionism in the region and in Singapore. In mid-1940s, unions are reported to cause disruptions through engaging in militancy; their attitude led the government to co-opt with the private sector to cool down militant unionism (Ibid: 489). Hiok (1995: 92) highlights, for instance, that the Singapore Factory and Shop Workers' Union was one of these unions which was involved in strikes that hit the operations of the colonial administration and the business sector. The experience with militant unionism paved the way to the so-called "responsible unionism" (Ibid: 490) which resulted in launch of the Singapore Trade Union Congress in 1950.

In the aftermath of People's Action Party's (PAP) seizure of the government in 1959, left wing leaders were arrested. Following the independence of Singapore from Malaysia, Rosa (1990: 491) claims that PAP had to put immense pressure on the labour movement that was conceived as a militant group which could have made foreign capital be wary of investing the small city-State, and the non-existence of a local bourgeois class to whom the labour movement could establish an alliance vis-à-vis the government, PAP found itself in

\footnotetext{
${ }^{7}$ To my best knowledge, there has not been any systematic study on whether the business sector does comply with the guidelines of the Council. It seems to be a fruitful area to make research on the rate of compliance of the business sector to the guidelines of the Council, and to control for the effect of this particular exemption on earnings inequality.

${ }^{8}$ Barr (2000) points out that the "inclusionary corporatist state" proposes several nuances for us not be misled by the structural setting of the institutions. Even though the author agrees that the upper ranks in the hierarchy of NTUC are filled with PAP MPs, the Secretary General of NTUC, Lim Boon Heng used to be involved with NTUC since the 1980s. His case can be interpreted as a career path starting with a role in NTUC to being a PAP MP. The so-called symbiotic relationship between NTUC and the government is well known; but it signals another important aspect of that special relationship such that the MPs can be both insiders and outsiders in NTUC as well as in the government. They can play both "hats" in different institutional contexts. Due to the fact that these officials and politicians can have such dual roles, the author concludes that trade unions - as well as the labouring class - can protect their interests; or at least expect to be protected by the government. Nevertheless, one can also interpret the structure to observe it depending on co-opting the position of the government and being a "responsible union" so as not to upset the social harmony.
} 
favourable conditions to limit the role of the unions. The strategy of PAP to incorporate unions to operate under the auspices of the government was the formation of the tripartite council. However, before that the government also "injected" civil servants by seconding them to the NTUC when they were preparing for wage claims in the tripartite council (Ibid: 492). Besides the role of the civil servants, Hiok (1995: 93) argues that 5 out of 21 members of NTUC were also PAP members of the Parliament. As long as these conditions and industrial relations are concerned, the historical evolution of unionism, and how unions were incorporated into the system under the control of the government lead us to interpretation according to power resource theory, unions were and are still subordinated to the control of the government. It seems to be very much challenging for the labouring class to have its voice heard at higher levels of decision-making, while letting alone restrictions on demonstrations and mass mobilisation. As discussed previously, the threat of communism, and the militant unionism persuaded the political elite; namely PAP, to be wary of not allowing greater space for the unions to manoeuvre.

As a small country, Singapore has always been an open economy. Intensification of internationalisation of the economy, and deregulation of labour market could be traced back to the 1980s. Deregulation of the labour market, which has become more friendly to lowskilled and highly-skilled migrants ${ }^{9}$ has had several implications on earnings equality (Low and Vadaketh, 2014); and for the role of the trade unions as well (Ching and Soon, 2000). With respect to higher trade liberalisation, structural shifts in demand for highly-skilled labour have been shown to have significant effect on polarisation in income distribution (Toh and Tat, 2012). The recession in the 1980s, rising wages, and concerns about competitiveness in a region mainly dominated by countries where costs related to investment and operations is less; Singapore opted for a deregulated labour market which welcomes massive influx of low-skilled and high-skilled migrants, alongside pressure on wages to moderate (Rao et al. 2003). As to the role of Council and guidelines it is providing to the whole economy with regard to wage policy, Ching and Soon (2000: 164) report that the wage council would no longer provide guidelines with certain percentage increases but rather wage increases in percentages; secondly they underline changes in the way how the labouring class would be remunerated. The remuneration will consist of the individual payment but it will reflect the health of national economy, performance of the firm, and the performance of the labourer (Ching and Soon, 2000: 164). A recently controversial issue of contributions and investments related to savings in the Central Provident Fund (CPF) has also changed; for instance, the employer contribution of 25 percent is expected to reflect the performance of the economy; meaning that if the economy is not doing well, the employers are flexible to contribute less to the savings account of each employee in CPF.

The evolution of the role of trade unions and a restricted level to play a greater role seems to have implications on earnings disparity in the country. As one may intuitively expect, even social policies may be directly or indirectly related to rising earnings inequality echoing this structural institutional environment. Asher and Nandy (2008) argue that the government cannot measure poverty because there is not a single statistical method to detect poverty; secondly tax regime favours firms and high-level income for which the rates have declined from 26 percent to 18 percent, and 28 percent to 20 percent, respectively from 2000 to

\footnotetext{
${ }^{9}$ In order not to make a distinction between what the Singaporeans call "foreign talent" to mark high-skilled labour; and "migrant workers" to label low-skilled labour; I prefer calling them low-skilled and high-skilled migrants because all migrants share the same identity of being a migrant regardless of their skills.
} 
2007. If we consider health policies, Asher and Nandy (2006) report that almost 70 percent of health spending is privatised; which means that individuals are responsible to take care of themselves; even if Figure 6 indicates a major upward shift in government spending on financing health expenses of the whole society. However, it is questionable if the unions were pushing the case because we need evidence of their proactive engagement in the shifts in the policy process. It seems more of responsiveness of the government to demands in the public sphere. ${ }^{10}$

Even the controversy on the question of minimum wage could well be explained with the power resources the labouring class holds to influence the policy process for a firm stance on this critical question of whether it would in fact benefit the whole society or not (Hui, 2013). Although it may sound as if a stretched version of the power resources theory, the role of the NTUC in influencing the political decision-making process on minimum wage is limited due to the centralised political institutional environment, and also the symbiotic relationship between the Singapore government and the NTUC. The NTUC Secretary-General Lim Swee Say told in 2013 that "[M]inimum wage can be a "zero-sum game". ${ }^{11}$ Based on that view, the NTUC came up with the proposal of a multi-tiered progressive (minimum) wage policy as the Secretary-General explains in 2013. The policy aims at increasing wages in the lower segments of the labouring class. If the workers are more productive and gain more skills, they may expect to earn more. The weakest part of the policy is that it does not introduce a compulsory minimum wage on the whole economic activity in the country. For a compulsory minimum wage policy is conceptualised as a "zero-sum game" by the NTUC, it seems very difficult to overcome such ideational impediments for the trade union to mobilise the labouring class for the introduction of the minimum wage. In Singapore, the role of trade unions, compared to that of in Switzerland, on minimum wage policy seems to be more of an ideational issue rather than challenges brought about by the political institutional setting. Although this might be the case at first sight, as argued earlier in this section that the policies of the Singapore government are mostly adopted by the NTUC due to close ties with the government; as a result, a deeper understanding would still tell us that the process is still determined because of the very centralised political environment in the country.

Finally, it would be important to touch upon recent measures taken by the Singapore government with the 2015 Budget which introduces higher taxation to higher income levels, increasing public spending on health and education. ${ }^{12}$ The measures are welcomed especially those on more public spending on social security, health, and education. With respect to higher taxation of higher levels of income, the Singapore government seems to pledge to take these measures as their implementation is starting next year, in 2016. Whether these measures would help Singapore reduce income inequality would depend on

\footnotetext{
${ }^{10}$ Responsiveness of the government may not prove power resource theory that is focusing on the relationships between the State, the labouring class and capital. The State, in theory, should be responsive to citizens' demands. Housing policy since independence reflects the degree of responsiveness of the government; which is labelled by Tremewan (1998) as "governance through welfare." The only concern in Singapore would be leaving the labouring class at the mercy of market forces through in some aspect decentralised wage bargaining. The State should be more active with providing mandatory guidelines to the private sector.

${ }^{11}$ The speech of the NTUC Secretary-General is available at on the website of the NTUC

http://www.ntuc.org.sg/wps/portal/up2/home/aboutntuc/newsroom/newshighlights/newshighlightsdetails?WCM_GLOBAL_CONTEXT=/CO ntent library/ntuc/home/about+ntuc/newsroom/newsthighlights/ace700004ecfeb748666af093c42a226, and on Channel News Asia http://www.channelnewsasia.com/news/specialreports/parliament/news/singapore-s-model-of-mini/596974.html accessed on April 2, 2015.

${ }^{12}$ For further information about these recent measures, the readers may refer to the website of the 2015 Budget available at http://www.singaporebudget.gov.sg/budget 2015/BudgetMeasures.aspx, accessed on April 2, 2015.
} 
several different, but interlinked factors; namely from the economic model, political dimensions, immigrant policy, among others. Additionally, it might be delusional to expect to observe impact of these policies in the short run, because there is always time lag between implementation and observation of the outcome. Last but not least, public policies tend to produce beneficiaries around them. The Singapore government reacted public debate on low public spending and low taxation of higher levels of income. It will need to control the process, if the government would not want to (over)stretch itself with more pledges. This is important given the trilemma in a service-dominated economy, as argued earlier, a shift from a "neoliberal" stage to some sort of a "social democratic" stage will require to forego fiscal discipline. At this point of time, it is difficult to assess whether the country can actually move toward a "social democratic" stage in the following years, or we should carefully assess what such a shift would mean for employment, income inequality in Singapore.

To sum up, this section endeavoured to highlight that a centralised and tripartite wagesetting institutional setting which is accompanied by a flexible and decentralised wagesetting environment at the firm-level; do not allow greater role to the labouring class to effectively channel demands for better working and earnings conditions. The militancy of unions and the efforts to encounter a communist threat, the government incorporated the labour movement in the tripartite Council. It also seconded the confederation of the labour movement, NTUC, through locating PAP MPs on its board and the hierarchical structure. One can suspect that the cultural orientation of "responsible citizens" (Nasir and Turner, 2013) are at the same time "responsible" union members, or even if they are not, they are responsive not to upset the delicate balance between economic performance, societal relations, and the social fabric in the tiny city-State. Even if that might be the case, the poor are poor in a rich country (Verwij and Pelizzo, 2009). The city-State can be considered to be vulnerable to foreign corporations, and more or less mobile human capital. One important implication we can derive from the influx of migrant workers might be on the role of unions. Migrants, if they are considering to be neutralised in the future, may solely be motivated by their material wellbeing; as a result they may not be engaged in the labour movement that can channel their demands to the government too. From the perspective of the government and the private sector, the higher the number of foreigners can indeed shift pressure on the local labour because these two actors can ask more from the Singaporeans to catch up with the foreigners in terms of productivity. One can suspect if inflow could be utilised for governance purposes of capital but also that of the government. If this can be proven, then power resources of the labouring class should not be expected to be higher vis-à-vis the other two actors in wage-determination, since they can be marginalised more and more due to lower wages a migrant may ask.

\section{Conclusion}

Income inequality has become a global concern. The Singaporean and the Swiss cases show in this chapter, it has had an upward trend in these two countries as well. This chapter endeavoured to explain the rise in income inequality with respect to the relative strength of trade unions, as representatives of the labouring class when the political decision on wage policies, and related social policies are negotiated with the State and capital-owners. The power resource theory would predict that the more power resources unions would accumulate vis-à-vis other actors, the more they could exert influence on policies which can 
improve socio-economic conditions of the labouring class, so that inequality could be reduced. If they do not hold a certain level of power resources, one could expect to see dominance of preferences of the State and the capital-owners. ${ }^{13}$ The aim of this chapter is very focused and does not engage in a "horse race" kind of presenting different determinants of rising income inequality in Singapore and Switzerland. It rather aims at showing the reader that relative power of trade unions in an era of declining union density might be an important indicator for better understanding of one of the determinants of the recent phenomenon. One might well come up with other determinants such as collective bargaining coverage (Salverda and Mayhew 2009; Bosch 2015), trade openness and financial deregulation resulting in premium for skilled labour (Krugman 1995; Goldberg and Pavcnik 2007; Jerzmanowski and Nabar, 2013) or even differences in occupational wages and so forth. These are assumed to be somehow intertwined, and they require a holistic assessment, which is out of the scope of this chapter.

Keeping in mind the limitations and the narrow scope of this chapter, we can claim that in Switzerland, the institutional structure that is built upon on a federal social welfare system that is accompanied by the unique institution of direct democracy did not allow the fragmented labour union movement to influence policy-making at the federal level. The lack of militant labour movement, the strong presence of a "third sector", and governments that have for a long-time being been dominated by the so-called "bourgeois" governments resulted in lower levels of social spending and an increasing income inequality. The recession in the early 1990s, which had hit hard the labouring classes, prepared the level for the labouring class to mobilise through centralising the unions across the cantons. As the labouring class overcame its own collective action problem by reforming the unions to be more centralised and try to be more active at the federal level, they have become more influential in receiving concessions from the capital-owners and the State on wage policies and other social policies. The Swiss case, at least partially, shows that the higher degree of power resources the labouring class has accumulated, they were able to influence the decision-making process. Although one may claim that their attempt with the recent popular vote on minimum wage is contradictory to the conclusion presented above, it should be noted that in such multi-tiered decision-making systems, reaching a consensus is a slow process. It is emphasised in this chapter that recognition of benefit of collective effort is notable despite the need to observe how this process will evolve.

In the Singaporean case, the centralised wage determination, the tripartite institutional context within the National Wage Council, and probably the most important factor of a oneparty dominated political system had not - and still does not - allowed the labouring class to mobilise itself to have a greater say in the decision-making process. The ideological orientation of the key decision-makers such as Mr. Lee Kuan Yew, and the first Chairman of the Wage Council reflects why they were sceptical of passing rigid wage policies, or letting the "militant" unions more space in the political arena as long as economic, political, and social externalities are taken into account. In Singapore, it seems evident that the centralised

\footnotetext{
${ }^{13}$ This should not be understood as the State may not desire to play a constructive role or be responsive to the demands of the labouring class. Populist regimes, political concerns especially before elections, etc. are well known determinants of expansionary spending in developing countries as well as developed countries where it is a rare case due to established rules and practice in macroeconomic management. However, as Iversen and Wren (1998) predict, the State may not be able to spend beyond its budgetary limits; because of which it may need to resort to fiscal discipline. As a result, the labouring class cannot force the State to adopt a more expansionary spending to reduce inequality; provided if the labouring class has a relatively lesser degree of power resources.
} 
political institutional context did not open enough space for the labouring class and its representatives to hold greater amount of power resources.

To sum up, as the power resource theory predicts, the cases tell us that the relative strength of the labouring class does matter in their role and reach in the political decision-making process of wage and social policies. A centralised or a decentralised political structure poses different challenges for the labouring class. The initial point at which the labour movement is positioned may not matter much. The Swiss case because as the context changed in the 1990s, the Swiss unions were able to overcome collective action problem in a decentralised political structure. However, the Singaporean case is a tricky case insofar as the role of the centralised political structure limits the space for the unions to play a constructive role in policy decision-making process. The evolution of income inequality seems that it will all depend on how responsive the Singaporean government is to demands of the population, rather than mobilisation of the labour movement, if there are any, compared to the Swiss case.

\section{References}

Acemoglu, D. 2012. The World Our Grandchildren will Inherit: The Rights Revolution and Beyond.

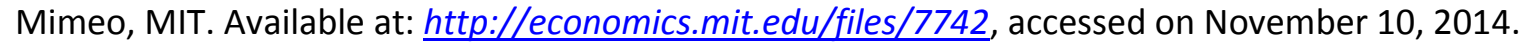

Armingeon, K. 2001. Institutionalising the Swiss Welfare State. West European Politics 24(2): 145-168.

Asher, M. and Nandy, A. 2006. Health Financing in Singapore: A Case for Systemic Reforms. International Social Security Review 59(1): 75-92.

Asher, M. and Nandy, A. 2008. Singapore's Policy Responses to Ageing, Inequality and Poverty: An Assessment. International Social Security Review 61(1): 41-60.

Barr, M. D. 2000. Trade Unions in an Elitist Society: The Singapore Story. Australian Journal of Politics and History 46(4): 480-496.

Baur, M., Bruchez, P. and Schlaffer, B. 2013. Institutions for Crisis Prevention: The Case of Switzerland. Global Policy 4(Supplement 1): 10-21.

Beck, T. et al. 2001. New Tools in Comparative Political Economy: The Database of Political Institutions. World Bank Economic Review 15(1): 165-176.

Bertozzi, F. and Bonoli, G. 2003. Fédéralisme et Protection Sociale en Suisse: Entre Immobilisme et Innovation. Sociétés Contemporaines 51: 13-33.

Bosch, G. 2015. Shrinking Collective Bargaining Coverage, Increasing Income Inequality: A Comparison of five EU Countries. International Labour Review 154(1): 57-66.

Butschi, D. and Cattacin, S. 1993. The Third Sector in Switzerland: The Transformation of the Subsidiarity Principle. West European Politics 16(3): 362-379.

Cattacin, S. 2006. Retard, Rattrapage, Normalisation. L'Etat Social Suisse face aux défis de Transformation de la Sécurité Sociale. Studien und Quellen - Etudes et Sources $31:$ 49-78. Available 
http://www.idheap.ch/idheap.nsf/webvwFichier/17522B21105ECFOAC1257782004997CC/SF ILE/RPL+2007+texte+10.pdf, accessed on November 11, 2014.

Durant, W. and A. 1968. The Lessons of History. New York: Simon and Schuster.

Dutt, P. and Mitra, D. 2008. Inequality and the Instability of Polity and Policy. The Economic Journal 118(531): 1285-1314.

Esping-Andersen, G. 1985. Politics Against Markets. Princeton: Princeton University Press.

Galbraith, J. K. 2012. Inequality and Instability: A Study of the World Economy Before the Great Crisis. New York: Oxford University Press.

Goldberg, P. K. and Pavcnik, N. 2007. Distributional Effects of Globalization in Developing Countries. Journal of Economic Literature 45(1): 39-82.

Hiok, L. B. 1995. Trade Union Growth in Singapore. Asian Journal of Political Science 3(2): $90-$ 111.

Hirschmann, A. O. 1970. Exit, Voice, and Loyalty: Responses to Decline in Firms, Organizations, and States. Cambridge, MA: Harvard University Press.

Hui, W. T. 2013. Economic Growth and Inequality in Singapore: The Case for a Miminum Wage. International Labour Review 152(1): 107-123.

Iversen, T. and Wren, A. 1998. Equality, Employment, and Budgetary Restraint: The Trilemma of the Service Economy. World Politics 50(4): 507-546.

Jaumotte, F. and Buitron, C. O. 2015. Power from the People. Finance and Development 52(1): 29-31.

Jerzmanowski, M. and Nabar, M. 2013. Financial Development and Wage Inequality: Theory and Evidence. Economic Inquiry 51(1): 211-234.

Kaldor, Nicolas. 1956. Alternative Theories of Distribution. The Review of Economic Studies 23(42): 83-100.

Katzenstein, P. J. Small States in World Markets: Industrial Policy in Europe. Ithaca: Cornell University Press.

Krugman, P. 1995. Growing World Trade: Causes and Consequences. Brookings Papers on Economic Activity 26(1): 327-377.

Korpi, W. 1983. The Democratic Class Struggle. London: Routledge and Kegan Paul.

Lasswell, H. 1958[1936]. Politics: Who Gets What, When, How. New York: McGraw-Hill.

Lee, K. Y. 2014. The Battle for Merger. Singapore: Straits Times Press.

Lim, C. Y. 2014. Singapore's National Wage Council: An Insider's View. New Jersey: World Scientific. 
Linder, W. 1994. Swiss Democracy: Possible Solutions to Conflict in Multicultural Societies. New York: St. Martin's Press.

Linder, W. and Vatter, A. 2001. Institutions and Outcomes of Swiss Federalism: The Role of Cantons in Swiss Politics. West European Politics 24(2): 95-122.

Lipset, S. M. 1983. Radicalism or Reformism: The Sources of Working-class Politics. The American Political Science Review 77(1): 1-18.

Low, D. and Vadaketh, S. T. 2014. Hard Choices: Challenging the Singapore Consensus. Singapore: NUS Press.

Mahbubani, K. 2014. Lee Kuan Yew's Complex Legacy. In Shashi Jayakumar and Rahul Sagar (eds.) The Big Ideas of Lee Kuan Yew. Singapore: Straits Times Press.

Meltzer, A. and Richard, S. 1981. A Rational Theory of the Size of Government. Journal of Political Economy, 89(5): 914-27.

Nasir, K. M. and Turner, B. S. 2013. Governing as Gardening: Reflections on Soft Authoritarianism in Singapore. Citizenship Studies 17(3-4): 339-352.

Obinger, H. 1998. Federalism, Direct Democracy, and Welfare State Development in Switzerland. Journal of Public Policy 18(3): 241-263.

Obinger, H. 1999. Minimum Income in Switzerland. Journal of European Social Policy 9(1): 29-47.

Obinger, H. et al. 2005. Switzerland: The Marriage of Direct Democracy and Federalism. In Herbert Obinger, Stephan Leibrief and Francis G. Castles (eds.) Federalism and the Welfare State, pp. 263-304. Cambridge: Cambridge University Press.

Oesch, D. 2011. Swiss Trade Unions and Industrial Relations after 1990: A History of Decline and Renewal. In Christine Trampusch and André Mach (eds.) Switzerland in Europe: Continuity and Change in the Swiss Political Economy, pp. 82-102. Oxon: Routledge.

Piketty, T. 2014. Capital in the Twenty-First Century. Cambridge, MA: Harvard University Press.

Pierson, P. 1995. Fragmented Welfare States: Federal Institutions and the Development of Social Policy. Governance 8(4): 449-478.

Polanyi, K. [1944]1975. The Great Transformation. New York : Octagon Books.

Poulantzas, N. 1973. On Social Classes. New Left Review 78: 27-54.

Rao, V. V. B., Banerjee, D. S. and Mukhopadhaya, P. 2003. Earnings Inequality in Singapore. Journal of the Asian Pacific Economy 8(2): 210-228.

Régnier, P. T. 1987. Singapour et son Environnement Régional: Étude d'une cité-État au sein du Monde Malais. Paris : Presses Universitaires de France.

Rosa, L. 1990. The Singapore State and Trade Union Incorporation. Journal of Contemporary Asia 20(4): 487-508. 
Salverda, W. and Mayhew, K. 2009. Capitalist Economies and Wage Inequality. Oxford Review of Economic Policy 25(1): 126-154.

Stockhammer, E. 2011. Wage-led Growth: An Introduction. International Journal of Labour Research 3(2): 167-187.

Toh, R, and Tat, H. W. 2013. Trade Liberalization, Labor Demand Shifts and Earningsss Inequality in Singapore. Review of Urban \& Regional Development Studies 24(3): 65-82.

Trampusch, C. 2010. The Welfare State and Trade Unions in Switzerland: An Historical Reconstruction of the Shift from a Liberal to a Post-Liberal Welfare Regime. Journal of European Social Policy 20(1): 58-73.

Tremewan, C. 1998. Welfare and Governance: Public Housing under Singapore's Party-State. In Roger Goodman, Gordon White and Huck-ju Kwon (eds.) The East Asian Welfare Model: Welfare Orientalism and the State, pp. 77-105. London \& New York: Routledge.

Verweij, M. and Pelizzo, R. 2009. Singapore: Does Authoritarianism Pay? Journal of Democracy 20(2): 18-32.

Wagschal, U. 1997. Direct Democracy and Public Policymaking. Journal of Public Policy 17(2): 223-245.

Wallerstein, M. 1999. Wage-Setting Institutions and Pay Inequality in Advanced Industrial Societies. American Journal of Political Science 43(3): 649-680. 